\title{
The Role of Brand Equity in Influencing Rural Bank Depositors
}

\author{
Sri Wahyuni, Taufiq Akbar*, Edy Sukarno \\ Faculty of Economics and Business \\ Perbanas Institute \\ Jakarta, Indonesia \\ *taufiq.akbar@perbanas.id
}

\begin{abstract}
The interest rate of savings and deposits in rural bank is higher than commercial bank, however, the level of thirdparty funds of rural bank is far below the commercial bank. This study tried to evaluate the elements of brand equity used by rural banks. A research was carried out in Bekasi, Indonesia, to identify the brand equity of some of rural banks. The respondents were 61 rural bank depositors in Bekasi chosen using snowball sampling techniques which were analyzed using structural equation modelling. We found evidence that the significant factor that affected rural bank depositors on brand loyalty was perceived quality. Meanwhile, this research cannot prove the influence of trust, brand awareness and brand association on brand loyalty. The results of the study proved that the role of perceived quality in influencing brand loyalty is high, and rural banks have not maximized the use of other elements in brand equity in their business activities.
\end{abstract}

Keywords: rural bank, brand equity, moderating effect, rural bank depositor

\section{INTRODUCTION}

Bank is a financial institution that acts as an intermediary between those who have excess funds and those who need funds. Funds raised by rural bank are savings and time deposits in rupiah units. Interestingly, based on data from the Indonesian Banking Statistics issued by the Financial Services Authority in Indonesia, the interest offered by rural bank is higher than the interest offered by other commercial banks in Indonesia. In 2018, the average savings interest offered by rural bank was $3.44 \%$, while the interest on commercial bank was merely $2.3 \%$. Furthermore, the deposit interest offered by rural bank is higher than the interest offered by other commercial banks. However, in total rural banks' third-party funds are far below the funds of third party owned by commercial banks.

Bank is basically a company engaged in service. Because rural bank is a service company, rural bank must continuously improve the service provided to its customers. If we compare the funding performance conducted by rural bank and commercial bank as mentioned before, more strategies are needed for rural bank to improve their funding performance. The strategy that can be done to improve the performance of service companies includes creating substantial value for the brand or brand equity [1].
Brand equity has four main elements, namely: perceived quality, brand awareness, brand association and brand loyalty [2]. This research focuses on the effect of perceived quality and trust on brand loyalty. Referring to the aforementioned research problems, the lack of public interest in saving at the bank may be caused by public's perceived quality, and trust in the products and services offered by rural bank are not as high as perceived quality and trust in products and services offered by commercial bank. Therefore, the effect of perceived quality and trust on brand loyalty becomes the primary variable that will be discussed in this study. In this case, the important factors for banks in creating loyalty of their customers are quality and trust [3].

Furthermore, because perceived quality and trust are things that must be built by the bank, it is required to have trust and good quality to attract customer loyalty. Therefore, another strategy is needed to increase public interest and loyalty on choosing products and services offered by rural bank. Brand awareness and brand association are elements of brand equity that can strengthen customer loyalty [4].

Based on the explanation above, we formulate the model based on the theory and events that happen in the rural bank. The model focuses on dimensions of brand equity as a strategy that can strengthen rural bank performance. The first analysis focuses on the effect of perceived quality and trust of rural bank depositors on their decision to select rural banks or to be loyal on the brand of rural banks. It is because quality and trust are the main line business that should be owned by bank [5,6]. Afterwards, we analyze the role of brand association and brand awareness as an additional strategy that is used as a factor that can strengthen the influence of perceived quality and trust in brand loyalty. It is because brand awareness and brand association can strengthen customer loyalty [7,8]. Therefore, we are interested in conducting a research on the role of brand awareness and brand association in moderating the effect of trust and perceived quality on brand loyalty on rural bank in Indonesia.

\section{METHOD}

Quantitative approach was used in this study by testing hypotheses. In addition, structural equation modelling analysis was used by testing both outer and inner models. Evaluation of the reflective outer model was done by testing the validity and 
reliability of the indicators. After conducting the outer model test, an indicator of test or a test of causality between variables was carried out using the statistical t-test and r-square value test. The sampling technique used was snowball sampling. The research respondents were rural bank depositors living in Bekasi, Indonesia. Bekasi was chosen as the study site because Bekasi is one of the areas with the highest population in Indonesia. A total of 61 respondent depositors were selected as respondents. They were considered sufficient, considering the variables studied in this study were 5 variables, where the minimum number of samples is 10 times the number of variables studied [9]. In this study, the minimum samples that must be obtained were 50, while the number of respondents in this study were 61 respondents.

\section{RESUlTS, ANALYSIS AND DISCUSSION}

As explained earlier, the respondents in this study were 61 respondents consisting of 30 male respondents and 31 female respondents. $60 \%$ of the total respondents were above 40 years-old, $28 \%$ of the total respondents were between 31-to-40years-old, while the respondents under 30-years-old were $26 \%$ from total respondents. Most of the respondents or about $69 \%$ respondents graduated from Senior High School and Under $31 \%$ had a diploma degree and above. $38 \%$ of respondents were entrepreneur, $39 \%$ of the respondents were private employees, $23 \%$ of respondents were housewives and other professions. $30 \%$ of respondents have net income of more than $5,000,000$ rupiahs per month, $36 \%$ have net income between $3,100,000$ rupiahs to $5,000,000$ rupiahs per month and $34 \%$ have net income between $1,000,000$ rupiahs to $3,000,000$ rupiahs per month.

Based on the results of the inferential analysis, it can be concluded that the model built has passed the outer model test where the results of the analysis indicate that all values of the factor loading testing, average variance extracted and communality were more than 0.5 . It means that the model has passed the convergent validity test. The model under study has also passed the discriminable validity test shown by all the average root variance extracted values that were more than the latent variable correlation value, and the cross-loading value was more than 0.7 . The model under study has also passed the reliability test; it can be seen from the value of Cronbach's alpha and composite reliability, i.e. 0.7.

After the model studied passed the outer model test, then the inner model testing was done. The value of degree of freedom was 56. Where the number of respondents was 61 and the number of variables was 5 . With a significance level of $10 \%$, it produced a t-table value of 1.67252 . $t$ value calculated from the effect of perceived quality on brand loyalty was 1.74885. The effect of perceived quality on brand loyalty showed that the $t$ value was greater than the t-table. It means that perceived quality has a significant influence on brand loyalty. Meanwhile, the influence of trust, brand awareness and brand association on brand loyalty showed that the $t$ value was $0.66735,1.150814$ and 0.442214 , respectively. The $t$ value of the three relations of these variables was smaller than the value of $\mathrm{t}$ table. It shows that trust, brand awareness and brand association do not have significant influences on brand loyalty.
The relationship of brand awareness in moderating the influence of perceived quality and trust on brand loyalty showed that $t$ value was 0.451904 and 0.680679 . Both of them have smaller $\mathrm{t}$ value than $\mathrm{t}$ table. It proved that brand awareness has not significantly moderated the effect of perceived quality and trust on brand loyalty on rural bank depositors. Like brand awareness, brand association has not significantly moderated the effect of perceived quality and trust on brand loyalty on rural bank depositors. It was proven by the $t$ value of the brand association relationship in moderating the effect of perceived quality and trust on brand loyalty were 1.325052 and 1.058698 . Both $\mathrm{t}$ values were not greater than $\mathrm{t}$ table values.

The study also found that value of coefficient determination was 0.7252 or $72.52 \%$. It means that the proportion of exogenous variables in influencing brand loyalty is very high. This result also shows that there are other exogenous variables outside the examined exogenous variables that can affect brand loyalty with a value of $28.48 \%$. The results of $t$ test prove that only perceived quality has a significant effect on brand loyalty on rural bank depositors. It can be concluded that the contribution of perceived quality on brand loyalty is high. Therefore, if further research will examine the factors affecting brand loyalty, it must include perceived quality as the main exogenous variable, especially on depositors of rural bank.

\section{A. The influence of Perceived Quality on Brand Loyalty}

Theoretically, customer perception of quality is the main thing that must be considered by the company, especially bank. Bank service improvement will provide convenience for customers in using products and services offered by bank. Conversely, customer inconvenience of products or services provided by bank can cause customer to choose another bank. The quality of the bank's products and services can lead to perceived quality for customers. When perceived quality from the customer of bank products and services is increasing, it will lead customer to be loyal in bank's brand [4,7].

The results of this study show that the interest rate of depositor in rural banks is influenced by perceived quality. This is because the interest offered by rural bank is higher than other commercial banks. In addition, it can also be concluded that the services offered by rural bank depositors have gone well. The good service offered by these depositors must be maintained or improved, considering that from several indicators of brand equity, only perceived quality can affect the brand loyalty of rural bank depositor. It is in line with previous research stating that perceived quality has significant influence on brand loyalty [5,7].

From these results, we recommend rural bank continuously improve the quality of products and services in rural bank operation. In addition, rural bank should make perceived quality as the main focus that must be carried out to increase customer loyalty. As stated in previous studies, an increase in perceived quality will give a significant impact on willingness to order and brand loyalty $[10,11]$. 


\section{Moderation Effect of Brand Association}

\section{B. The Influence of Trust on Brand Loyalty}

Theoretically, customers trust is a sense of security when interacting with a product or service offered by the company to the customers. This sense of security can arise in the minds of bank customers when the bank has a reputation or has certain credibility for the products it offers. As defined by several experts, a bank is a business that relies on the trust held by its customers. When customers have no longer trust in products offered by bank, the customers will withdraw their money from the bank. As a result, bank will have liquidity problems that will cause bankruptcy. On the contrary, when there is a customer's trust in using products offered by bank, it can increase customer loyalty on the bank [6].

These results show that trust does not have a significant effect on brand loyalty. Therefore, we can conclude that trust is not the main variable for rural bank depositors to transact with them. In addition, we can also conclude that perceived quality is a more dominant variable than trust in influencing brand loyalty. However, different things might happen when customer trust is decreasing. The decline in customer trust will cause customer loyalty to the company decreases [6]. Therefore, trust is not a major factor in increasing brand loyalty, however, we recommend rural bank management to prioritize trust in serving their depositors.

\section{Moderation Effect of Brand Awareness}

Brand awareness is synonymous with the memory that is owned by customers about the company's brand. Theoretically, the memory can arise from the attributes owned by the company for the brand of products and services it offers. A deep memory of a product offered by the company will increase customer sensitivity to the brand and customer loyalty on the brand [8]. Therefore, brand awareness owned by the company can increase the intensity of transactions carried out by customers. The perceived quality and trust in the products and services offered by the bank is deemed insufficient to increase the loyalty of bank customers. Thus, the perceived quality and trust built by the bank must be supported by customer awareness of the bank's brand. Then, the attributes owned by bank become something that can form brand awareness and it must contribute to strengthening perceived quality and trust in increasing customer brand loyalty.

Theoretically, brand awareness should be a means to strengthen the influence of perceived quality and trust on brand loyalty. However, from the results of a survey on rural bank depositors, it was found that the level of brand awareness of rural bank depositors was still low. It seems that the use of the attributes of rural bank in influencing customer loyalty has not been carried out maximally [12]. Therefore, brand awareness cannot moderate the effect of perceived quality and trust on brand loyalty. The weak brand awareness of rural bank depositors should be the main concern to strengthen the company's brand performance. Brand awareness should be used as a strategy to increase brand loyalty. It is in line with the results of previous studies stating that brand awareness can increase customer loyalty [4].
In the era of globalization, the level of competition between banks is increasingly high. It is possible that customers have the same perception of the quality and trust in the products and services owned by the bank. Therefore, perceived quality and trust are considered insufficient to attract the interest of bank's customers in using the products and services offered by banks. The image or brand association of the bank can increase the customer's intention in making transactions using bank products. Customers can be interested in using a product because the company has an image that attracts customers in choosing products offered by bank [4]. Brand awareness can be a part that can increase bank customer loyalty. In addition to perceived quality and trust that owned by bank's customer, bank must have brand association to strengthen the influence of perceived quality and trust on brand loyalty.

However, the results of the study are unable to prove that brand association can moderate the relationship from perceived quality and trust to brand loyalty. Like brand awareness, brand association has not proven affecting brand loyalty. Apparently, rural bank does not have a strong image in forming brand associations [12]. Therefore, brand association cannot moderate the effect of perceived quality and trust on brand loyalty. As explained earlier, rural bank should have a brand association to increase customer loyalty. This must be a concern of management in managing rural bank. Considering it in the realization, rural banks generally serve the public that is not affordable by commercial banks, such as farmers, fishermen, small traders, breeders, employees, and retirees. This can be used as an element in forming a rural bank brand association.

\section{CONCLUSION}

The results of this study prove that only perceived quality has a significant effect on brand loyalty on rural bank depositors. This study found that trust, brand awareness and brand loyalty did not have a significant effect on brand loyalty on rural bank depositors. Therefore, brand awareness and brand association have not significantly moderated the effect of perceived quality and trust on brand loyalty on rural bank depositors. Based on the results, it turns out that rural banks in Bekasi have not used brand equity as a strategy maximally. Therefore, to increase public interest, rural banks in Bekasi should use brand equity as a strengthening strategy, especially in brand awareness and brand associations. In addition, because the results of the study indicate that trust has no significant influence on brand loyalty, the rural banks management in Bekasi must strengthen public trust on the products and services they provide.

\section{ACKNOWLEDGMENT}

This research was supported by the Indonesian government in this case the Ministry of Research, Technology and Higher Education of the Republic of Indonesia (KEMENRISTEK DIKTI) and Perbanas Institute as the main support in terms of material and other supports in conducting the research. Therefore, we would like to thank to the KEMENRISTEK DIKTI and Perbanas Institute for all dedication to this research. 
[7] C. Kocoglu, D. Tengilimoglu, A. Ekiyor, and A. Guzel, "The Effects of Brand Loyalty on The Consumer Buying Behaviors: The Example of Perfume in The Province Of Ankara," Int. J. Humanit. Manag. Sci., vol. 3, no. 5, pp. 318-323, 2015.

[1] S.R. Satvati, M. Rabie, and R. Rasoli, "Studying the Relationship Between Brand Equity and Customer Behaviour," Int. Rev., vol. 1, no. 2, pp. 153-163, 2016.

[2] D.A. Aaker, Building Strong Brands. New York: Free Press, 1996.

[3] H.M.W. Rasheed, J. Khalid, H.M.U. Khizar, M. Sajid, M.N. Shahid, M. Ahmad, and W.A. Khan, "Factors affecting customer loyalty in banking sector: A study on banks in Bahawalpur (Pakistan)," International Journal of Accounting and Financial Reporting, vol. 5, no. 1, pp. 239254, 2015.

[4] R. Chinomona and E.T. Maziriri, "The Influence of Brand Awareness, Brand Association and Product Quality on Brand Loyalty and Repurchase Intention: A Aase of Male Consumers for Cosmetic Brands in South Africa," J. Bus. Retail Manag. Res., vol. 12, no. 1, pp. 143-154, 2017.

[5] V. Mirabi, H. Akbariyeh, and H. Tahmasebifard, "A Study of Factors Affecting on Customers Purchase Intention Case Study: the Agencies of Bono Brand Tile in Tehran,” J. Multidiscip. Eng. Sci. Technol., vol. 2, no. 1, pp. 267-273, 2015.

[6] P.W.J. van E. Plasmeijer and W.F. van Raaij, "Banking System Trust, Bank Trust, and Bank Loyalty," Int. J. Bank Mark., vol. 35, no. 1, pp. 97-111, 2017.

[8] R.A.A. Naggar and N. Bendary, "The Impact of Experience and Brand Trust on Brand loyalty, while Considering The Mediating Effect of Brand Equity Dimensions, An Empirical Study on Mobile Operator Subscribers in Egypt.," Bus. Manag. Rev., vol. 9, no. 2, pp. 16-25, 2017.

[9] U. Sekaran and R. Bougie, Research methods for business: a skillbuilding approach / Uma, 7th ed. Chichester: John Wiley \& Sons Ltd., 2016.

[10] A. Santoso and A. Aprianingsih, "The Inluence of Perceived Service and E-Service Quality to Repurchase Intention The Mediating Role of Customer Satisfaction Case Study: Go-Ride in Java," J. Bus. Manag., vol. 6, no. 1, pp. 32-43, 2017.

[11] M. Falahat, C.S. Chuan, and S.B. Kai, "Brand Loyalty and Determinates of Perceived Quality and Willingness to Order," Acad. Strateg. Manag. J., vol. 17, no. 4, pp. 1-10, 2018.

[12] A.M. Alkhawaldeh, S.M. Salleh, and F. Bin Halim, "Brand Equity and Brand Loyalty: New Perspective," Int. Rev. Manag. Mark., vol. 6, no. 4, pp. 722-730, 2016. 